\title{
THE EFFECT OF CORPORATE GOVERNANCE REGULATIONS IN STOCK MARKETS ON BOARD AND CAPITAL STRUCTURES OF COMPANIES: AN APPLICATION ON BORSA ISTANBUL
}

\author{
DOI: 10.17261/Pressacademia.2019.1113
}

JEFA- V.6-ISS.3-2019(4)-p.142-158

\section{Cuneyd Ebrar Levent}

Istanbul Aydin University, Anadolu BIL Vocational School, Kucukcekmece, Istanbul, Turkey. cuneydebrarlevent@gmail.com ,ORCID: 0000-0003-1494-3029

Date Received: August 8, 2019

Date Accepted: September 12, 2019

\section{To cite this document}

Levent, C.E. (2019). The effect of corporate governance regulations in stock markets on board and capital structures of companies: an application on Borsa Istanbul. Journal of Economics, Finance and Accounting (JEFA), V.6(3), p.142-158.

Permemant link to this document: http://doi.org/10.17261/Pressacademia.2019.1113

Copyright: Published by PressAcademia and limited licenced re-use rights only.

\section{ABSTRACT}

Purpose- Regulators seek to intervene directly or indirectly in the management styles and financial structures of companies in order to ensure the transparent and efficient functioning of the market, as well as to protect investors. The aim of the study is to determine the effect of corporate governance regulations in stock markets on board and capital structures of the industrial companies listed on Borsa Istanbul (BIST). Methodology- The study covers the period 2010-2014, including the period during which policy changes took place in Turkey. The sample consists of 134 companies listed in BIST Industry Index and traded continuously during this period. Non-parametric statistical tests are used for the effect of regulations on management structure, while the effect on capital structure is analyzed by panel regression analysis

Findings- The results show that the regulations have a significant effect on establishment of an internal audit system, the inclusion of independent directors on board and board size. However, there is no statistically significant effect of the regulations on capital structures (leverage) on both pooled model and fixed effect models.

Conclusion- The evidence presented in the study suggests the necessity of the regulations and enforcements for public companies in the field of corporate governance. The results of the study are expected to shed light on not only researchers but also policy makers and regulatory bodies.

Keywords: Financial markets, financing policy, corporate governance, regulations, board size.

JEL Codes: G30, G32, G38

\section{INTRODUCTION}

Deepening of globalization of financial markets, trade wars and competition between countries and companies, merge and acquisitions, particularly require publicly traded companies to be more aware of the risks in this environment. Regional and global crises and corporate collapses, which have been running on since the end of the 90s, have made the necessity of the concept of corporate governance indisputable. Since stakeholders such as companies, shareholders, investors, creditors, suppliers, customers, states are more closely connected to each other than in the past, the solution of the problems is not to seek another approach to replace corporate governance. Regulatory bodies have to play a leading role and make reforms that will ensure the survival and development of an effective and transparent market by analyzing the shortcomings of corporate governance and being aware of the balance between stakeholders.

Dealing with corporate governance regulations, the issue should not be viewed only from the legal or just from financial perspective. The relationship between law and finance (La Porta et al., 1998) is multidimensional, in contrast to the traditional finance model (Modigliani \& Miller, 1958) that deals with the cash flow dimension of securities. Equity securities provides its shareholders not only with capital gain or dividend, but also the right to elect board of directors and auditors and remove them and to vote on critical matters (Anderson \& Gupta, 1999). Addressing this aspect, Kose \& Senbet (1998) defined corporate governance as the control of various legal stakeholders over a company by making use of certain rights specified in the existing legal and regulatory frameworks as well as corporate bylaws.

There is no universally agreed-upon definition of corporate governance and excellent model that could be applied for all countries. Thus, corporate governance regulations should also be realized by taking into account factors such as the economic 
structure of the country, the business culture, the structure of the financial markets and the characteristics of the labour force.

The launch of the OECD Corporate Governance Principles and the entry into force of the Sarbanes-Oxley Act in the United States have influenced many countries to establish their own corporate governance codes or principles. But, after the 2008 Global Economic Crisis, in many countries the principles generally hardened and some turned into mandates. In this way, the regulators aimed to change the corporate governance culture by including concepts such as independent members, nonexecutive members, committees, continuous disclosure and early detection of risk in the management styles of the companies.

The aim of this study is to determine the effect of corporate governance regulations in stock markets on board and capital structures of industrial companies listed on Borsa Istanbul. In line with trends in developed and developing countries, especially after the year 2011, major regulations were realized in the field of corporate governance in Turkey. Corporate governance principles were redefined, policy changes were made and some principles were mandated. This study analyzes the reaction of companies to these changes by examining pre and post-regulation.

While there have been numerous studies on the effects of policy changes, particularly in the economic literature, there have been not enough studies on emerging markets concerning the consequences of corporate governance arrangements. In addition, a multidisciplinary approach to the effects of legal regulations on both management and board as well as financial studies have not been found. This study aims to fill the gap in the literature in this respect.

The study is structured as follows: In the second section following this introduction part of the study, literature review and hypothesis development are presented. Section 3 includes data and methodology. In the section, before introducing the data set used in the research, information about the corporate governance environment and regulations in Turkey is described and the relationship of these regulations with established models is explained. In addition, since the research involves multiple different methods and tests, brief information about these tests is given. Section 4 presents empirical results and discussion. Section 5 concludes the study with a discussion of the contribution, limitations and recommendations for future research.

\section{LITERATURE REVIEW AND HYPOTHESIS DEVELOPMENT}

This section consists of five sub-sections: corporate governance quality, internal audit, independent members, board structure and capital structure. Firstly, in each subsection, the related studies are reviewed the literature. Then, the issue is discussed in the context of corporate governance regulations and finally the hypotheses to be tested are presented.

\subsection{Corporate Governance Quality}

There is no consensus on the definition of corporate governance, so the literature contains many studies that try to define the quality of corporate governance with different approaches. The issue was discussed with the phrase "good corporate governance" in the Cadbury Report (Cadbury Commitee, 1992), which is regarded as the first set of principles on corporate governance. In the literature, the term of "well-governed" in various studies are assessed with different dimensions of corporate governance such as corporate governance rating, board effectiveness, transparency and disclosure (Bauer, Guenster, \& Otten, 2004; Solomon \& Solomon, 2004; Wang \& Hussainey, 2013; Grosman, 2015; Abdallah \& Ismail, 2017).

However, it is obvious that a firm which is effective, able to make decisions quickly and that is taking care of the rights of investors but does not have independent members on the board should not be judged as "poor quality" according to a single criteria. Or a firm that has independent members and creates the committees only because of the mandates but does not actually implement them, should not be considered as a "quality" firm in terms of corporate governance. For these reasons, it would not be right to approach corporate governance and corporate governance quality with a single dimension and a single mechanism.

In the light of these considerations it can be argued that measuring corporate governance quality at company level with welldesigned indices is a good practice. There are numerous studies in the literature that attempt to measure the quality of corporate governance with indices. However, there are different approaches to this issue. The first of these are the indices conducted by researchers based on universal corporate governance principles (Black, de Carvalho, \& Gorga, 2012). In the second approach, the indices are prepared by taking into account the legislation of the country where the research is conducted (Gompers, Ishii, \& Metrick, 2003; Garay \& González, 2008; Achim \& Borlea, 2014). The third approach is to use open source indices developed by various rating agencies (such as $S \& P$ ) and to follow their methodology (Khanna, Palepu, \& Srinivasan, 2004; Durnev \& Kim, 2005; Aksu \& Kösedağ, 2006; Grosman, 2015; Arsov \& Bucevska, 2017). Finally, it is seen that some researchers prefer to use the corporate governance ratings in the indices (whose content is generally known only by these institutions) created by various institutions or investment banks (Klapper \& Love, 2004). 
Regulatory authorities, one of the determinants of a country's corporate governance environment, are responsible for ensuring that financial markets operate transparently and effectively. Improving corporate governance quality cannot only be achieved by the efforts of the companies, but regulators allocate a trustable area for both companies and investors. In order for this to happen, the framework of corporate governance under the leadership of the state and regulatory bodies in a country needs to be established. This framework should encourage transparent and efficient markets, be consistent with the law and clearly demonstrate the division of responsibilities among the various supervisory, regulatory and enforcement authorities (OECD, 2004). In this respect, regulations may affect the quality of corporate governance (Larcker, Ormazabal, \& Taylor, 2011; Martynova \& Renneboog, 2011). Hence the following hypothesis is therefore tested:

Hypothesis 1: Corporate governance regulations is related with the corporate govervance quality.

\subsection{Internal Audit}

Having an effective internal audit system is considered as one of the most important elements of good corporate governance practice. The financial statements and annual reports of public companies are audited by independent external auditors and the results of the audits are disclosed to the public. Auditing is performed by independent auditors, why is internal audit needed? To find the answer to this question, it would be useful to review the definition of internal audit. According to the IIA's (The Institute of Internal Auditors) International Professional Practices Framework;

"Internal auditing is an independent, objective assurance and consulting activity designed to add value and improve an organization's operations. It helps an organization accomplish its objectives by bringing a systematic, disciplined approach to evaluate and improve the effectiveness of risk management, control, and governance processes" (THEIAA, n.d.)

This definition reveals that internal audit also has functions which can not be performed by external audit such as adding value to the activities of the company, improving its activities and helping the company to achieve its objectives. Eulerich, Kremin and Wood (2019) examined the issue within the framework of agency theory, emphasized that the internal audit function is an agent of both executive management and audit committee. According to the authors, internal audit provides assurance and consultancy to these two stakeholders while providing their information needs.

Because of these functions, regulatory bodies recommend companies to establish an internal audit system (Mahzan \& Yan, 2014). It has been emphasized that internal audit activity should be involved in improving the corporate governance process and contribute to ensuring accountability. Therefore, the concept of internal audit is included in international corporate governance principles (OECD, 1999, 2004, 2015) and corporate governance codes of various countries (Ntim, Opong, \& Danbolt, 2012). Although the regulations do not generally require an internal audit system, the obligation of the audit committee and the fact that this committee is also responsible for the internal audit unit can be considered as a factor that will indirectly force public companies in this respect. Thus:

Hypothesis 2: Corporate governance regulations are effective for companies to establish internal audit systems.

\subsection{Independent Board Members}

One of the most emphasized issues regarding corporate governance at firm level in both literature and practices is the presence of independent members on boards. The need for independent members stems from the fact that the executive members are involved in the daily activities of the firm and are considered unable to protect the interests of stakeholders because they are regarded as related party. The Cadbury Report highlighted that independent members who were not exposed to less direct influence could help resolve situations such as conflict of interest (Cadbury Commitee, 1992).

In addition to preventing conflicts of interest, independent members are expected to provide companies with vision, different perspectives and support in strategy and risk management with their knowledge and experience. Corporate governance literature provides numerous studies about whether independent directors improve firm performance. Some studies concluded that the presence of independent members improves firm performance (Choi, Park, \& Yo, 2007; Mura, 2007; Zhu, Ye, Tucker, \& Chan, 2016). Bhagat and Bolton (2013) found a significant and positive relationship between board independence and operational performance after the Sarbanes Oxley Act. However, some studies did not find any statistical evidence that the independence of the board affects firm performance (Ferris \& Yan, 2007; Johl, Kaur, \& Cooper, 2015).

The debate about the need for independent members to be included in the regulations has actually been discussed for a long time. Baysinger and Butler (1985) mentioned the importance of independent board members in the board composition and emphasized that the proportion of independent managers in corporate governance reform should be a potential performance variable. Wintoki and $\mathrm{Xi}$ (2019) stated in their research on the cost of compliance with the regulators after the Sarbanes Oxley Act that the main purpose of the law was to directly change and regulate the board structure of the firms. The authors emphasized that this change was achieved by mandating independent board committees and by tightening the definition of independence rather than stricter listing rules. Especially in the aftermath of the 2008 Global Financial Crisis, it has become mandatory to have independent board members on boards of public companies in many countries. Hence: 
Hypothesis 3: Corporate governance regulations are effective for companies to inclusion independent directors on boards.

\subsection{Board Structure}

Board structure has been a topic of interest not only in the field of management but also in economic theory (Fama \& Jensen, 1983). The main reason for this is that the board of directors is at the central of corporate governance mechanisms in the market economies and is viewed as the primary way for shareholders to exercise control over top management (Kose \& Senbet, 1998).

Different approaches can be seen in the literature regarding the board size. Monks and Minow (2004), Arora and Sharma, (2016) emphasized that more board members could provide more information, more experience and more effectiveness. There are also empirical studies supporting this approach. Acaravcı, Kandır and Zelka (2015), Johl, Kaur and Cooper (2015), Tulung and Ramdani (2018) found that board size was positively correlated with firm performance. Nevertheless, in some studies, it was found that the composition of the board is not associated with the firm value (Hermalin \& Weisbach, 1991). On the other hand, there are empirical results in the literature, which found a negative and significant relationship between board size and firm value (Yermack, 1996; Kumar \& Singh, 2013; Azeez, 2015)

In general, both in the corporate governance principles and regulations for listed companies, there is no recommendation or obligation regarding the size of the board of directors. The matters related to the firm's board of directors are generally regulated by the corporate laws. Corporate governance reforms, however, impose a number of requirements such as establishment of committees, board independence. All these factors may affect the structure of the board of directors of companies. Thus:

Hypothesis 4: Corporate governance regulations have an impact on the size of the board of directors.

\subsection{Capital Structure}

One of the most important features that differentiates the corporate governance approach from some other management theories is that it is directly related to financial issues. The fairness principle of corporate governance includes issues such as facilitating voting for all shareholders (Klapper \& Love, 2004). These shareholders are the persons or groups that make up the equity in the firm's balance sheet and have rights to the assets of the firm. The transparency principle also includes accurate and timely disclosure of matters relating to the financial position of the company (including debt structure), its ownership structure and its operating results (OECD, 2004). Board accountability in the general meeting, independent audit, internal audit and internal control are the requirements of the accountability principle, where financial elements are dominant. The principle of responsibility implies that companies should take into account the interests of parties involved in the company's activities when making decisions and planning (West, 2009). These parties (stakeholders) include lenders, creditors and suppliers as well as shareholders.

When examining the relationship between corporate governance and capital structure, it is useful to consider these issues mentioned above. Board size, board independence, the presence of the internal audit system, are in fact linked to the protection of the company's assets, the avoidance of unnecessary risks of the company, and the protection of the "Balance between Debt and Total Assets" (leverage). Consequently, the quality of corporate governance mentioned in the previous subsections can be considered as a factor that carries the potential to affect the leverage.

There are different research results in the literature on the impact of corporate governance on leverage. Jiraporn et al. (2012) stated that the overall quality of corporate governance has a significant impact on critical financial decisions such as capital structure choices. The authors examined the firms reported in Institutional Shareholder Services (ISS) and found a strong inverse relationship between corporate governance and leverage. This indicates that firms with poor governance are significantly more leveraged. Nadarajah et al. (2018) examining the companies listed in the Australian Securities Exchange (ASX) also found a significant and negative relationship between corporate governance quality and leverage. This shows that having high corporate governance quality significantly reduces the leverage of firms. Detthamrong et al. (2017) who examined Thai companies investigated the relationship between corporate governance, capital structure and firm performance. The authors found that corporate governance is not associated with financial leverage and firm performance.

Corporate governance regulations for public companies are likely to have an impact not only on their board structures but also on their financing policies. Arping and Sautner (2010) investigated the impact of the Corporate Governance Code on financing policy in the Netherlands in 2004. The authors argued that reform would improve the monitoring of managers and that this would reduce the value of debt as a means of discipline. The results supported this hypothesis and showed that after the reform, the leverage ratios of Dutch firms decreased significantly. Consequently, although regulations do not foresee what the leverage of firms should be, the necessity of certain principles (risk committee, audit committee, independent member, etc.) has the potential to affect the capital structure of companies. Hence:

Hypothesis 5: Corporate governance regulations have an impact on the capital structure of companies. 


\section{DATA AND METHODOLOGY}

This section provides information about the research examining the effects of corporate governance regulations in Turkey on the board and capital structure of public companies. Since the research covers Turkey, in the first instance the environment of corporate governance in Turkey, corporate governance codes and requirements are mentioned. Then, the scope of the research, data and methodology designed according to this legal framework are emphasized.

\subsection{Corporate Governance in Turkey and Scope of the Research}

After the Cadbury Report (Cadbury Commitee, 1992) and the OECD Principles of Corporate Governance (OECD, 1999), the concept of corporate governance started to be discussed in the academic and business environment in Turkey as well as in the world. However, in Turkey, the fact that the issue came up on the basis of "principle" under the name of "corporate governance" reached the end of 2002. In 2001, biggest crisis in the Turkish financial history occurred and many companies, especially banks and financial institutions, went bankrupt or collapsed. The results of this crisis revealed Turkey's need for structural reform, stricter regulations were introduced in many areas, especially banking, new regulation bodies were established or were increased the powers of the existing regulators. As for corporate governance, the first Corporate Governance Code was proposed in 2002 by the Turkish Industry and Business Association, a business non-governmental organization (TUSIAD, 2002). Based on OECD principles, this code focused more on board-related issues of publicly traded or large companies such as the board structure, board operation, CEO Duality. Although not mandating, this code laid the base for the publication of the "CMB Corporate Governance Principles" in 2003 by a regulatory body, the Capital Markets Board (CMB).

The Corporate Governance Principles, published by CMB in 2003 and updated in 2005, included not only the issues related to the board members, but also the rights of shareholders, disclosure and transparency, the function of independent audit and the rights of stakeholders (CMB, 2003, 2005). Public companies did not have to comply with these principles until 2011. However, all companies except the companies excluded from the regulations were obliged to disclose whether they comply with these published corporate governance principles. if not, they are obliged to state the reasons to the public in the annual report as "Corporate Governance Compliance Report".

Prior to the 2011 reform, Borsa Istanbul (formerly the Istanbul Stock Exchange), the regulatory body responsible for stock exchanges in Turkey, created the Corporate Governance Index (XKURY) in 2007 to encourage the managing of public companies within the framework of corporate governance principles (BIST, 2019). In order to be included in the Corporate Governance Index, public companies were required to have a Corporate Governance Report prepared by authorized and independent rating agencies and to disclose these corporate governance ratings to the public. Today, this regulation is valid, and the reports of the companies with corporate governance ratings have been announced at KAP (Public Disclosure Platform), another regulatory body.

In 2011, important reforms were made in the field of corporate governance. The Corporate Governance Communiqué, which was in force since 2005, repealed and Corporate Governance Codes were redefined. Some basic corporate governance principles were become compulsory for the listed companies. Companies were given time to make these arrangements in their articles of association at their general meetings until June 30, 2012. In 2012, 2013 and 2014, the CMB clarified certain provisions with its communiqués (CMB, 2019).

These regulations in the field of corporate governance constitute the main motivation of this study. Therefore, the study covers the period between 2010-2014 including pre-regulation and post-regulation as time periods.

To create a balanced data set and to test the hypotheses mentioned in the previous section, public companies listed continuously between 2010 and 2014 on Borsa Istanbul (BIST) are identified as the main population of the study. In order to minimize the impact of the sectoral difference, the data of listed companies in the BIST Industrial Index (XUSIN) on Borsa Istanbul are used in the research.

More detailed information about the data set and methodology is provided below.

\subsection{The Data Set}

In spite of the fact that the chronology of principles associated with public companies in Turkey began in 2003, the most important regulations affecting the management and financial structures of companies began in 2011 and lasted until 2014. As mentioned above, the data set is built to cover the period between 2010 and 2014. Between 2010 and 2014, there were 146 companies in the industrial sector in BIST. However, according to the BIST rules, 134 of these companies were included in the XUSIN index during this period. Therefore, the data set of this study consists of these 134 companies. The distribution of the companies covered by the research (in the XUSIN index) by sub-sectors is reported in Table 1. Accordingly, Non-Metal Mineral Product and Metal Product, Machinery sub-sectors take the first two places with $19,40 \%$. 
Table 1: Distribution of Companies by Sub-Sectors

\begin{tabular}{lcc}
\hline Sub-Sectors & Number of Firms & $\%$ \\
\hline Food and Beverage & 18 & $13.43 \%$ \\
\hline Textile, Leather & 17 & $12.69 \%$ \\
\hline Wood, Paper, Printing & 13 & $9.70 \%$ \\
\hline Chem, Petrol, Plastic & 19 & $14.18 \%$ \\
\hline Non-Metal Mineral Product & 26 & $19.40 \%$ \\
\hline Basic Metal & 13 & $9.70 \%$ \\
\hline Metal Products, Machinery & 26 & $19.40 \%$ \\
\hline Mining & 2 & $1.49 \%$ \\
\hline Total & $\mathbf{1 3 4}$ & $\mathbf{1 0 0 . 0 0 \%}$ \\
\hline
\end{tabular}

Note: The sub-sector classification was taken from the Public Disclosure Platform (KAP, 2019)

The total market value of the companies covered by the research is 110.7 billion TL (approximately 71.5 billion USD). Table 2 presents the frequencies of the market values. Market values are calculated based on the year-end closing values and financial statements. According to this table, 53.73\% of the companies' market value is below 250 million TL (approximately 161.6 million USD).

Table 2: Distribution of Companies by Market Values

\begin{tabular}{lcc}
\hline Market Value (millions of Turkish Lira) & Number of Firms & $\%$ \\
\hline Less than 25 & 6 & $4.48 \%$ \\
\hline $25-50$ & 13 & $9.70 \%$ \\
\hline $50-100$ & 22 & $16.42 \%$ \\
\hline $100-250$ & 31 & $23.13 \%$ \\
\hline $250-500$ & 13 & $9.70 \%$ \\
\hline $500-750$ & 18 & $13.43 \%$ \\
\hline $750-1,000$ & 7 & $5.22 \%$ \\
\hline $1,000-2,500$ & 13 & $9.70 \%$ \\
\hline $2,500-5,000$ & 6 & $4.48 \%$ \\
\hline More than 5,000 & 5 & $3.73 \%$ \\
\hline Total & $\mathbf{1 3 4}$ & $\mathbf{1 0 0 . 0 0 \%}$ \\
\hline
\end{tabular}

Note: In the frequency table, the lower value represents an integer value and the upper value represents a decimal value (such as $2,499.99)$. This type of frequency presentation is preferred for understanding the table.

In the study two types of data are collected as financial and non-financial data. The data set consists of both cross-sectional and time series data. Financial data are obtained from Borsa Istanbul (BIST) and Public Disclosure Platform (KAP). Nonfinancial data are collected from official sources such as annual reports, independent audit reports and corporate governance compliance reports disclosed in KAP. In addition, disclosures (such as information on the board structure) that companies have to submit periodically to regulatory bodies and announced to the public have been utilized. Since the data set covers the years 2010-2014, this type of data collection method, which is used in many corporate governance researches in literature (Achim \& Borlea, 2014; Germain, Galy, \& Lee, 2014) are preferred instead of survey method.

\subsection{Methodology}

As mentioned earlier, the aim of this study is to determine the effects of corporate governance regulations for public companies on the management and financial structures of the companies and the methodology has been determined to serve this purpose. The effects of the regulations on the different dimensions of the management structures of the companies are examined with Cochran's Q Test, McNemar Test and Friedman Test. The determination of the impact on capital structures is analyzed by Difference-in-Differences method and panel regression analysis. SPSS and Stata programs are used in the analyzes.

The variables used in the research are listed as follows: 
Corporate Governance Quality (CGQ): In Turkey, according to the regulations which is being implemented since 2007, it has been not mandatory for public companies to have a corporate governance rating. The corporate governance rating is determined only by rating companies authorized by the CMB and their compliance with corporate governance is assessed with more than 300 criteria (Saha, 2019). At the end of the rating process, the company's rating is announced to the public at KAP. This process helps both to determine the corporate governance level of the company and to address its shortcomings in the future. Therefore, in this study, the company's rating is considered as an indicator of corporate governance quality. In the study, CGQ is considered as a binary variable, the company gets 1 value $(C G Q=1)$ if it gets a corporate governance rating, and $0(C G Q=0)$ if it doesn't.

Presence of Internal Audit System (IAUD): According to the Corporate Governance Principles published in 2011 and 2012, it was mandatory for public companies to establish audit committees in their boards of directors. However, according to the legislation valid between 2010 and 2014, companies did not have to establish internal audit systems unlike the audit committee. However, the regulations indirectly recommended that companies establish internal audit systems. Therefore, in this study, establishing internal audit systems is considered as a factor that can affect the board structures of companies. In this study, IAUD is considered as a binary variable. If the company establishes an internal audit system, it gets 1 value (IAUD $=1)$ and if it does not, it gets $0(I A U D=0)$.

Presence of Independent Directors on the Board (IND): According to the Corporate Governance Principles published by CMB in 2003 and 2005, companies were recommended to have independent members on their boards of directors. This recommendation became mandatory in 2011 and the companies were given time until June 30, 2012 to fulfill this requirement. While some companies included independent directors on the board of directors before the obligaton, others made changes towards the end of the period. In the study, IND is considered as a binary variable, the company gets 1 value $(I N D=1)$ if the company includes independent directors on the board, and $0(I N D=0)$ if it doesn't.

Board Size (BSIZE): Making certain corporate governance principles mandatory for public companies is likely to change the board structures of companies that are not ready for regulation. On those grounds, in the study the companies' board size before and after the regulation are compared and they are analyzed whether there is a significant difference. BSIZE variable represents the number of board members.

Capital Structure (BLEV): The capital structure is represented by book leverage and is expressed in the following equation (1):

$$
B L E V=\frac{\text { Short term debt }+ \text { Long term debt }}{\text { Total assets }}
$$

POST: Post is dummy variable indicating whether the period is post-reform. In the pre-reform period (2010 and 2011), the value of 0 is taken as 1 in the post-reform period.

TREAT: Treat is a dummy variable used in the Diffrence-in-Differences method to separate the control and treatment groups. The variable gets 1 if the company is in the treatment group and 0 when it is in the control group.

TREATXPOST: This dummy variable is used in Diffrence-in-Differences estimation. It expresses the product of TREAT variable and POST variable (TREAT X POST).

Firm Size (LNSIZE): Control variable. Firm size is represented by the natural logarithm of total assets. Firm size, as in this study, is included in the analysis as control variable in many studies in the literature (Yermack, 1996; Larcker, Ormazabal, \& Taylor, 2011; Tulung \& Ramdani, 2018).

Liquidity (LIQD): Control variable. Liquidity is represented by the ratio of current assets to current liabilities and is expressed by the following equation (2):

$$
\text { LIQD }=\frac{\text { Current Assets }}{\text { Current Liabilities }}
$$

Fixed Assets to Total Assets (FIXED): Control variable that is represented by the ratio of fixed assets to total assets and is expressed by the following equation (3):

$$
\text { FIXED }=\frac{\text { Fixed Assets }}{\text { Total Assets }}
$$

In the study, the hypotheses mentioned in Section 2 are tested with the following tests: 
Cochran's Q Test: Cochran's Q test is used to test Hypothesis 1, Hypothesis 2 and Hypothesis 3 in this study. Cochran's $Q$ test is a non-parametric test used to determine whether there are differences in frequency or proportions between more than two dependent groups. Dependence may be the same individual's views on different issues, or the same individual's responses at different times. The most important characteristic that distinguishes this test from other paired group tests is that the result of each variable must be only 1 or 0 (dichotomous variable).

The matrix form of Cochran's Q test can be expressed as: (Lou \& Fu, 2007):

$$
\boldsymbol{X}=\left(\begin{array}{cccc}
X_{11} & X_{12} & \cdots & X_{1 b} \\
X_{21} & X_{22} & \cdots & X_{2 b} \\
\vdots & \vdots & X_{i j} & \vdots \\
X_{K 1} & X_{K 2} & \cdots & X_{K b}
\end{array}\right)
$$

where $X_{i j} \in\{0,1\}$ is the dichotomous response for the $i_{\text {th }}$ treatment in the $j_{\text {th }}$ block .

For dichotomous responses in k matched group, the Cochran's Q test statistic is computed. Cochran (1950) found that for large samples, $Q$ statistic is distributed as chi-square with $k-1$ degrees of freedom.

The null hypothesis of Cochran's $Q$ test is developed as follows:

$H_{\circ}$ : The proportion (ח) of "successes (1)" is the same in all k groups

$\mathrm{H}_{\mathrm{o}}: \Pi_{0}=\Pi_{1}=\ldots .=\Pi_{\mathrm{k}}$

versus the alternative is that the proportion is different in at least one of $k$ groups

$H_{A}: \Pi_{a} \neq \Pi_{b}, a \neq b$ and $a \geq 1, b \leq k$

McNemar Test: In this study, the McNemar test is used to find significant differences between the paired groups if the null hypothesis of Cochran's $Q$ test in Hypothesis 1, Hypothesis 2 and Hypothesis 3 is rejected $(\Pi a \neq \Pi b)$. The McNemar test is a non-parametric test comparing the distributions of two related groups when the dependent variable is dichotomous (Fleiss, Levin, \& Paik, 2003). This test consists of just two groups, as before-after or as success-failure, as in Cochran's $Q$ test.

McNemar test statistic is calculated by the following formula (4): (Sheskin, 2000; Fleiss, Levin, \& Paik, 2003)

$$
\chi^{2}=\frac{\left(n_{12}-n_{21}\right)^{2}}{n_{12}+n_{21}}
$$

where $n_{i j} \in\{0,1\}$ is the dichotomous response for the $i_{\text {th }}$ treatment in the $j_{\text {th }}$ block .

The null hypothesis of McNemar test is developed as follows:

$H_{0}$ : The proportion ( $\Pi$ ) of "successes (1)" is the same in all two groups

$\mathrm{H}_{\mathrm{o}}: \Pi_{0}=\Pi_{1}$

versus the alternative is that the proportion is different in two groups

$\mathrm{H}_{\mathrm{A}}: \Pi_{0} \neq \Pi_{1}$

Friedman Test (Friedman two-way analysis of variance by ranks): In the study, Friedman test is used to test Hypothesis 4. Friedman test is used to test whether there is a significant difference between distributions by comparing the distributions of two or more related (dependent) variables. Friedman test has a similar matrix structure as given in Cochran's $Q$ test above. However, unlike the Cochran's $Q$ test, the Friedman test is used when the results are not dichotomous.

Friedman test statistic is calculated by the following formula (5) (Sheskin, 2000):

$$
\chi_{r}^{2}=\frac{12}{n k(k+1)}\left[\sum_{j=1}^{k}\left(\Sigma R_{j}\right)^{2}\right]-3 n(k+1)
$$


Where

$\mathrm{k}=$ number of groups (conditions)

$\mathrm{n}=$ number of subjects

$\mathrm{R}=$ sum of the ranks

The null hypothesis of Friedman test is developed as follows:

$H_{0}$ : There no difference between the $k$ groups medians

$H_{0}: \theta_{1}=\theta_{2}=\ldots \theta_{k}$

versus the alternative is that the median is different in at least one of $\mathrm{k}$ groups

$H_{A}: \theta_{a} \neq \theta_{b}, a \neq b$ and $a \geq 1, b \leq k$

Wilcoxon Test (Wilcoxon signed-rank test): In this study, Wilcoxon test is used to find significant differences between the paired groups in case the null hypothesis of Friedman test is rejected in Hypothesis 4. Since the Wilcoxon test is widely used, it is not mentioned in details.

Difference-in-Difference Estimation (DID): DID estimation is used to test Hypothesis 5 in the study. Differences-in-differences is simple panel-data method applied to sets of group means in cases when certain groups are exposed to the causing variable of interest and others are not and this approach is well-suited to estimating the effect of sharp changes in the economic environment or changes in government policy (Angrist \& Krueger, 1999). Since this study also examines the effect of corporate governance regulations on capital structures of companies, the DID method is suitable for testing Hypothesis 5 in this respect.

The main regression model used in the research is formed as follows as used in the study by Arping and Sautner (2010):

$$
B L E V_{i t}=\alpha+\beta_{1} x \text { POST }+\beta_{2} x \operatorname{TREAT}_{i} x \text { POST }_{i}+\text { Controls }+\vartheta_{i}+u_{i t}
$$

The capital structure is represented by the book leverage (BLEV) as dependent variable. POST variable covers the post-reform period as mentioned above, taking the value "1" for 2012 and 2013 and " 0 " for 2010 and 2011. TREAT variable is used to separate companies in control and treatment groups. However, unlike in the study Arping and Sautner (2010), the IAUD variable is used here when determining treatment group companies. In other words, , the companies that have the internal audit system in $\mathbf{2 0 1 0}$ are taken into the treatment group and those that do not have it into the control group.

In econometric analysis, the time dimension ( $T$ ) remains short as a consequence of the difference-in-differences method (prepost). Therefore, considering the solutions proposed by Torres-Reyna (2007), standard errors are heteroskedasticity robusted.

In the next section, the findings are presented and discussed.

\section{FINDINGS AND DISCUSSIONS}

As stated before, there wasn't any obligation about that listed companies in Turkey comply with the corporate governance codes issued by the CMB in the period 2003-2011. On the other hand, companies were mandated to disclose whether or not to comply with these codes in the Corporate Governance Compliance Report. Table 3 displays the number of companies which disclosed the Report between 2010 and 2014. The results indicate that most of the companies disclosed the Report to the public.

Table 3: Corporate Governance Compliance Report Disclosure Frequency Distribution

\begin{tabular}{lcccc}
\hline Years & N & Report Disclosed & Report not Disclosed & $\%$ \\
\hline 2010 & 134 & 125 & 9 & $93.28 \%$ \\
\hline 2011 & 134 & 127 & 7 & $94.78 \%$ \\
\hline 2012 & 134 & 132 & 2 & $98.51 \%$ \\
\hline 2013 & 134 & 131 & 3 & $97.76 \%$ \\
\hline 2014 & 134 & 131 & 3 & $97.76 \%$
\end{tabular}


Cochran's $Q$ test results for the impact of regulations on general corporate governance quality are reported in Table 4. CGQ refers to the quality of corporate governance pre-regulation, and $\mathrm{CGQ}_{1}-\mathrm{CGQ}_{4}$ refers to the post-regulation. Cochran's $Q$ test results indicate that Hypothesis 1 is supported. The results show that the impact of corporate governance regulations in Turkey on general corporate governance quality is statistically significant between 2010 and 2014. McNemar test reported in Table 5 is used to test the periods in which this effect is significant. McNemar test results show that the effect is only statistically significant between $\mathrm{CGQ}_{0}-\mathrm{CGQ}_{3}, \mathrm{CGQ}_{0}-\mathrm{CGQ}_{4}$ and $\mathrm{CGQ}_{1}-\mathrm{CGQ}_{4}$, but is insignificant between other periods. It can be concluded that the positive impact of the policy change on the corporate governance quality will not be in such a short period of 1 or 2 years.

Table 4: Cochran's Q Test Results (CGQ)

\begin{tabular}{lcrrr}
\hline Variables & $\mathbf{N}$ & Cochran's Q & df & Asymp. Sig. \\
\hline $\mathrm{CGQ}_{0}, \mathrm{CGQ}_{1}, \mathrm{CGQ}_{2}$, & 134 & 16.7500 & 4 & $\mathbf{0 . 0 0 2 2} * * *$ \\
$\mathrm{CGQ}_{3}, \mathrm{CGQ}_{4}$ & & & & \\
\hline
\end{tabular}

Note: ${ }^{*}, *$, and ${ }^{* * *}$ indicate significance at $10 \%, 5 \%$, and $1 \%$ levels

Table 5: McNemar Test Results (CGQ)

\begin{tabular}{lccc}
\hline Variables & $\mathbf{N}$ & McNemar's Chi' (1) & Exact Sig. (2 tailed) \\
\hline $\mathrm{CGQ}_{0}-\mathrm{CGQ}_{1}$ & 134 & 1.00 & 1.0000 \\
\hline $\mathrm{CGQ}_{0}-\mathrm{CGQ}_{2}$ & 134 & 2.00 & 0.5000 \\
\hline $\mathrm{CGQ}_{0}-\mathrm{CGQ}_{3}$ & 134 & 5.00 & $\mathbf{0 . 0 6 3 0}$ \\
\hline $\mathrm{CGQ}_{0}-\mathrm{CGQ}_{4}$ & 134 & 6.00 & $\mathbf{0 . 0 3 1 0} * *$ \\
\hline $\mathrm{CGQ}_{1}-\mathrm{CGQ}_{2}$ & 134 & 1.00 & 1.0000 \\
\hline $\mathrm{CGQ}_{1}-\mathrm{CGQ}_{3}$ & 134 & 4.00 & 0.1250 \\
\hline $\mathrm{CGQ}_{1}-\mathrm{CGQ}_{4}$ & 134 & 5.00 & $\mathbf{0 . 0 6 3 0}$ \\
\hline $\mathrm{CGQ}_{2}-\mathrm{CGQ}_{3}$ & 134 & 3.00 & 0.2500 \\
\hline $\mathrm{CGQ}_{2}-\mathrm{CGQ}_{4}$ & 134 & 4.00 & 0.1250 \\
\hline $\mathrm{CGQ}_{3}-\mathrm{CGQ}_{4}$ & 134 & 1.00 & 1.0000
\end{tabular}

Note: ${ }^{*}, *$, and ${ }^{* * *}$ indicate significance levels at $10 \%, 5 \%$, and $1 \%$ levels

Table 6 presents Cochran's $Q$ test results for the impact of regulations on companies' establishing an internal audit system (IAUD). The results show that the null hypothesis that the regulations has no effect on establishing an internal audit system was strongly rejected. In Table 7, analyzing by McNemar Test it is determined between which two periods this effect are statistically significant. Unlike the results in Table 5, the results are statistically significant in all 9 remaining periods except for the period between 2010-2011. The reason for this can be explained as:

Under legislation in force in 2010-2014, companies were not required to establish internal audit systems. However, with the 2011 communiqué, it was made mandatory for public companies to establish audit committees in their boards of directors. Among the duties of the Audit Committee were to monitor the internal audit and internal control system. Although the regulations did not make the internal audit system mandatory, the requirement to establish an Audit Committee could

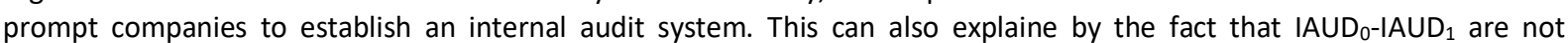
statistically significant. In summary, both the Cochran's $Q$ test and the subsequent McNemar test show that Hypothesis 2 is supported.

Table 6: Cochran's Q Test Results (IAUD)

\begin{tabular}{|c|c|c|c|c|}
\hline Variables & $\mathbf{N}$ & Cochran's Q & df & Asymp. Sig. \\
\hline $\begin{array}{l}I_{A U D_{0}}, I_{A U D_{1}}, I_{2} \mathrm{AUD}_{2} \\
\mathrm{IAUD}_{3}, \mathrm{IAUD}_{4}\end{array}$ & 134 & 68.7540 & 4 & $0.0000 * * *$ \\
\hline
\end{tabular}


Table 7: McNemar Test Results (IAUD)

\begin{tabular}{|c|c|c|c|}
\hline Variables & $\mathbf{N}$ & McNemar's Chi²(1) & Exact Sig. ( 2 tailed) \\
\hline $\mid A U D_{0}-I_{A} D_{1}$ & 134 & 1.00 & 0.5078 \\
\hline$I_{A U D_{0}}-I A_{2} D_{2}$ & 134 & 10.80 & $0.0014 * * *$ \\
\hline $\mathrm{IAUD}_{0}-\mathrm{IAUD}_{3}$ & 134 & 19.70 & $0.0000 * * *$ \\
\hline$I^{A} U D_{0}-I_{A} D_{4}$ & 134 & 26.56 & $0.0000 * * *$ \\
\hline$I_{A U D}-I_{1} A_{2}$ & 134 & 9.78 & $0.0026 * * *$ \\
\hline $\mathrm{IAUD}_{1}-\mathrm{IAUD}_{3}$ & 134 & 18.00 & $0.0000 * * *$ \\
\hline$I_{A U D}-I_{1} A_{4}$ & 134 & 23.68 & $0.0000 * * *$ \\
\hline$I_{A} \mathrm{AD}_{2}-\mathrm{IAUD}_{3}$ & 134 & 7.36 & $0.0117 * *$ \\
\hline$I_{A U D}-I_{2} A_{4}$ & 134 & 13.24 & $0.0003 * * *$ \\
\hline$I_{A U D}-I_{3} A_{4}$ & 134 & 6.00 & $0.0313 * *$ \\
\hline
\end{tabular}

The third hypothesis of this research is the effect of regulations on the presence of independent members in the boards of directors of companies. Table 8 shows presence of independent directors between 2010 and 2014. In 2010 only $14.18 \%$ of companies had independent members on their boards. This rate increased to $18.66 \%$ in 2011 . At the end of 2011 , two regulations were made. These regulations were about that public companies had to include independent members on their boards. For this reason, 98.51\% of the companies in 2012 and in 2013 and 2014 all had independent members on the board of directors.

Table 8: Presence of Independent Directors on the Board

\begin{tabular}{|c|c|c|c|c|c|}
\hline \multirow{2}{*}{ Variables } & \multirow{2}{*}{$\mathbf{N}$} & \multicolumn{2}{|c|}{ Frequencies } & \multicolumn{2}{|c|}{$\%$} \\
\hline & & Value $=0$ & Value $=1$ & Value $=0$ & Value $=1$ \\
\hline INDO & 134 & 115 & 19 & $85.82 \%$ & $14.18 \%$ \\
\hline IND1 & 134 & 109 & 25 & $81.34 \%$ & $18.66 \%$ \\
\hline IND2 & 134 & 2 & 132 & $1.49 \%$ & $98.51 \%$ \\
\hline IND3 & 134 & 0 & 134 & $0.00 \%$ & $100.00 \%$ \\
\hline IND4 & 134 & 0 & 134 & $0.00 \%$ & $100.00 \%$ \\
\hline
\end{tabular}

Table 9 reports the results of Cochran's $Q$ test for the effect of the regulations on having independent members on board of directors (IND). Due to the requirement of independent members in 2012, the time period is taken as 3 years to cover 20102012 instead of 5 years. It is not surprising that hypothesis 3 is supported, but the more striking result is given in the McNemar test in Table 10, which shows paired comparisons. The table indicates that statistically significant results are obtained in all three periods examined. Examining Table 8 and Table 10 together, it is seen that the majority of companies wait the requirement date (June 30,2012 ) to include independent members on their boards of directors.

Table 9: Cochran's Q Test Results (IND)

\begin{tabular}{lcrrr}
\hline Variables & $\mathbf{N}$ & Cochran's Q & df & Asymp. Sig. \\
\hline $\mathrm{IND}_{0}, \mathrm{IND}_{1}, \mathrm{IND}_{2}$ & 134 & 214.6370 & 2 & $\mathbf{0 . 0 0 0 0} * * *$ \\
\hline Note: $* * *$, and & $* * *$ indicate significance levels at $10 \%, 5 \%$, and $1 \%$ levels
\end{tabular}

Table 10: McNemar Test Results (IND)

\begin{tabular}{lccc}
\hline Variables & $\mathbf{N}$ & McNemar's Chi'(1) & Exact Sig. (2 tailed) \\
\hline $\mathrm{IND}_{0}-\mathrm{IND}_{1}$ & 134 & 6.00 & $\mathbf{0 . 0 3 1 3} * *$ \\
\hline $\mathrm{IND}_{0}-\mathrm{IND}_{2}$ & 134 & 113.00 & $\mathbf{0 . 0 0 0 0} * * *$ \\
\hline $\mathrm{IND}_{1}-\mathrm{IND}_{2}$ & 134 & 107.00 & $\mathbf{0 . 0 0 0 0} * * *$ \\
\hline Note: ${ }^{* * *}$, and & $* * *$ \\
\end{tabular}


The regulations require companies to have independent members on their boards of directors (Table 9 and Table 10), as well as to form an Audit Committee. This,- though not required-, leads companies to establish an internal audit system (Table 6 and Table 7). Do these requirements have an impact on the structure of the board of directors? Did the companies change the number of board members as they have to include independent board members on the board of directors? Or did they exclude some of the existing members from the board and choose independent members instead? In Hypothesis 4, the answer to these questions is actually sought. Table 11 shows the results of Friedman Test for this hypothesis.

Table 11: Friedman Test Results (BSIZE)

\begin{tabular}{|c|c|c|c|c|c|c|c|c|c|}
\hline \multirow[b]{2}{*}{ Variables } & \multicolumn{3}{|c|}{ Model 1} & \multicolumn{3}{|c|}{ Model 2} & \multicolumn{3}{|c|}{ Model 3} \\
\hline & $\mathbf{N}$ & $\mathrm{Chi}^{2}$ & Asmp.Sig & $\mathbf{N}$ & $\mathrm{Chi}^{2}$ & Asmp.Sig & $\mathbf{N}$ & $\mathrm{Chi}^{2}$ & Asmp.Sig \\
\hline $\begin{array}{l}\text { BSIZE }_{0}, \text { BSIZE }_{1}, \\
\text { BSIZE }_{2}\end{array}$ & 134 & 75.6944 & $0.0000 * * *$ & 34 & 23.2340 & $0.0000 * * *$ & 34 & 14.0000 & $0.0009 * * *$ \\
\hline
\end{tabular}

In Table 11, three different models are formed. In Model 1, all companies are included in the model. The Friedman test rejects the null hypothesis that regulations do not have an impact on board size. Therefore, the effect of corporate governance regulations on the structure of the board is statistically significant. In Model 2, Hypothesis 4 is tested on 34 companies with the highest market value (Quartile 1) and on Model 3 with 34 companies with the lowest market value (Quartile 3). The results are statistically significant in both models.

Table 12 reports the results of the Wilcoxon test, which compares the results in pairs. The results were statistically significant in all three models with $\mathrm{BSIZE}_{2}$ variable. When Table 11 and Table 12 are examined together, it is seen that public companies took action not in the year in which the regulations were made, but in the year in which the regulations came into force. The results in Table 12 show that large companies (with market value) are more affected by regulations than small firms (Model 2). That is; the regulation (mandate) for independent directors, especially in 2012, resulted in increasing the number of board members in the majority of large companies. 22 of the 34 companies expanded their board of directors when compared to the pre-regulation period. It is noteworthy that in companies with low market value (Model 3), there was almost no action $\left(\mathrm{BSIZE}_{1}-\mathrm{BSIZE_{0 }}\right)$ until the date when the regulation came into force.

Table 12: Wilcoxon Test Results (BSIZE)

\begin{tabular}{lcccccc}
\hline Model 1 & \multicolumn{7}{l}{ N } & Negative Ranks & Positive Ranks & Ties & Z statistics & Asymp. Sig. (2-tailed) \\
\hline Variables & 134 & 12 & 7 & 115 & $-0,972$ & 0.3311 \\
\hline BSIZE $_{1}-\mathrm{BSIZE}_{0}$ & 134 & 16 & 71 & 47 & $-6,974$ & $\mathbf{0 . 0 0 0 0} * * *$ \\
\hline $\mathrm{BSIZE}_{2}-\mathrm{BSIZE}_{0}$ & 134 & 12 & 77 & 45 & $-7,354$ & $\mathbf{0 . 0 0 0 0} * * *$ \\
\hline $\mathrm{BSIZE}_{2}-\mathrm{BSIZE}_{1}$ & & & & & & \\
\hline
\end{tabular}

\begin{tabular}{lcccccc}
\hline Model 2 & \multicolumn{1}{l}{} \\
\hline BSIZE $_{1}-\mathrm{BSIZE}_{0}$ & 34 & 5 & 3 & 26 & $-0,073$ & 0.9416 \\
\hline $\mathrm{BSIZE}_{2}-\mathrm{BSIIE}_{0}$ & 34 & 4 & 22 & 8 & $-3,985$ & $\mathbf{0 . 0 0 0 1} * * *$ \\
\hline $\mathrm{BSIZE}_{2}-\mathrm{BSIZE}$ & 34 & 5 & 25 & 4 & $-3,816$ & $\mathbf{0 . 0 0 0 1} * * *$ \\
\hline
\end{tabular}

\begin{tabular}{lllllll}
\hline Model 3 & \multicolumn{7}{l}{} \\
\hline $\mathrm{BSIZE}_{1}-\mathrm{BSIZE}_{0}$ & 34 & 1 & 0 & 33 & $-1,000$ & 0.3173 \\
\hline $\mathrm{BSIZE}_{2}-\mathrm{BSIZE}_{0}$ & 34 & 4 & 15 & 15 & $-3,272$ & $\mathbf{0 . 0 0 1 1} * * *$ \\
\hline $\mathrm{BSIZE}_{2}-\mathrm{BSIZE}_{1}$ & 34 & 3 & 15 & 16 & $-3,370$ & $\mathbf{0 . 0 0 0 8} * * *$ \\
\hline Note: ${ }^{* *}$, and
\end{tabular}

Note: ${ }^{*}, * *$, and $* * *$ indicate significance levels at $10 \%, 5 \%$, and $1 \%$ levels 
Table 13: Univariate Analysis (BLEV)

\begin{tabular}{lccc}
\hline BLEV & Treatment Group (Mean) & Control Group (Mean) & Difference (Treatment - Control) \\
\hline Pre Mandatory & 0.4398 & 0.4659 & -0.0261 \\
\hline Post Mandatory & 0.4794 & 0.4645 & 0.0149 \\
\hline & & & Difference-in-differences \\
\hline Difference (Post - Pre) & 0.0396 & -0.0014 & 0.0410 \\
\hline Note: ${ }^{*}, *$, and ${ }^{* * *}$ indicate significance levels at 10\%, 5\%, and 1\% levels &
\end{tabular}

In this study, the effect of corporate governance regulations on financial leverage of companies is analyzed by Difference-inDifference method. The financial leverage of the companies are examined in two separate periods, before the regulations came into force (2010-2011) and after (2012-2013). In addition, companies are divided into two groups as treatment and control group on the basis of the difference-in-difference method. Prior to the regulation, the companies that established an internal audit system in 2010 (46 companies) constitute the treatment group and the companies that did not ( 88 companies) constitute the control group. Table 13 shows the results of univariate analysis. Before the regulation, the average leverage of the treatment group companies increased from 0.4398 to 0.4794 after the regulation. In the control group, the leverage was 0.4659 before the regulation and decreased to 0.4645 after the regulation. There were no statistically significant differences in both pre-post (regulation) and treatment-control differences.

Table 14 shows the regression results. In econometric analysis, the time dimension $\mathrm{T}$ is short due to the application of the difference-in-differences method (pre-post). Therefore, taking into consideration the solutions proposed by (Torres-Reyna, 2007), heteroskedasticity robusted standard errors is performed. Following the approach by Arping and Sautner (2010) both pooled and fixed effect regressions are applied. Model 4, Model 5 and Model 6 provide pooled regression results. Model 7, Model 8 and Model 9 indicate the fixed effect panel regression analysis. In all models, the dependent variable is BLEV (Book Leverage), covering the period 2010-2013 (536 firm-year data). Prob. (F-statistic) values indicate that all models are significant.

In Model 4 and Model 7, only control variables are included in the regression equation. In both models, the LIQD variable is significant and negative with BLEV. LNSIZE (natural logarithm of total assets) is not significant in Model 4 (pooled regression) and significant and positive in Model 7 (fixed effect). The FIXED variable (Fixed Assets/Total Assets) is significant and negative in Model 4 and statistically insignificant in Model 7.

Table 14: Difference-in-Differences Regression Results

\begin{tabular}{|c|c|c|c|c|c|c|}
\hline \multicolumn{7}{|c|}{ Dependent Variable: BLEV } \\
\hline Independent Variables & Model 4 & Model 5 & Model 6 & Model 7 & Model 8 & Model 9 \\
\hline \multirow[t]{2}{*}{ TREATXPOST } & & & 0.2630 & & & $0.0110 * *$ \\
\hline & & & $(1.12)$ & & & (2.56) \\
\hline \multirow[t]{2}{*}{ POST } & & 0.7010 & 0.7850 & & 0.5500 & 0.1720 \\
\hline & & $(0.38)$ & $(-0.27)$ & & $(-0.60)$ & $(-1.72)$ \\
\hline \multirow[t]{2}{*}{ LNSIZE } & 0.1560 & 0.1520 & 0.1910 & $0.0230 * *$ & $0.0450 * *$ & $0.0420 * *$ \\
\hline & $(-1.42)$ & $(-1.44)$ & $(-1.31)$ & $(2.31)$ & $(2.02)$ & (2.05) \\
\hline \multirow[t]{2}{*}{ LIQD } & $0.0000 * * *$ & $0.0000 * * *$ & $0.0000 * * *$ & $0.0810 *$ & $0.0780 *$ & $0.0660 *$ \\
\hline & $(-3.87)$ & $(-3.87)$ & $(-3.87)$ & $(-1.76)$ & $(-1.78)$ & $(-1.86)$ \\
\hline \multirow[t]{2}{*}{ FIXED } & $0.0000 * * *$ & $0.0000 * * *$ & $0.0000 * * *$ & 0.9770 & 0.9680 & 0.8040 \\
\hline & $(-4.22)$ & $(-4.21)$ & $(-4.17)$ & $(0.03)$ & $(0.04)$ & $(-0.25)$ \\
\hline \multirow[t]{2}{*}{ TREAT } & & & 0.3630 & & & \\
\hline & & & $(-0.91)$ & & & \\
\hline Obs. & 536 & 536 & 536 & 536 & 536 & 536 \\
\hline R-sq & 0.3324 & 0.3326 & 0.3339 & 0.0926 & 0.0946 & 0.1114 \\
\hline Prob (F-statistic) & $0.0000 * * *$ & $0.0000 * * *$ & $0.0000 * * *$ & $0.0349 * *$ & $0.0660 *$ & $0.0011 * * *$ \\
\hline
\end{tabular}

Note: $*, * *$, and $* * *$ indicate significance levels at $10 \%, 5 \%$, and $1 \%$ levels. T-statistics are reported in paranthesis. 
In Model 5, POST variable is added to pooled regression equation. The POST variable is 0 for pre-regulation period and 1 for post-regulation period. The addition of the POST variable in this model is not lead to a significant relationship on BLEV. Adding the POST variable in the fixed effect method in Model 8 gives similar results.

In Model 6, the Difference-in-Difference Method is applied in pooled regression, and all independent and control variables are added to the equation. It is observed that the POST variable does not have a significant effect on BLEV.

According to the results of analysis which are summarized in Tablo 14, the Model 9 is determined as having the best explanatory variables for explaining relationship between regulations and capital structure. In this context Difference-inDifferences panel regression equation is as follows (7):

$$
B L E V_{i t}=\alpha+\beta_{1} x \text { POST }+\beta_{2} x \text { TREAT }_{i} x \text { POST }_{i}+\beta_{3} x \text { LNSIZE }_{i t}+\beta_{4} x \text { LIQD }_{i t}+\beta_{5} x \text { FIXED }_{i t}+\vartheta_{i}+u_{i t}
$$

In this model, although the TREATXPOST variable has a significant and positive relationship with BLEV, it is seen that the POST variable does not have a significant relationship with BLEV. It can be concluded from here that the leverages of the companies in the treatment group tend to increase after the regulations. However, what is sought in this regression equation is that the regulations will affect the leverage of the companies, which is not supported. Therefore Hypothesis 5 is rejected. This result is consistent with the results of the univariate analysis in Table 13, but does not support the results found by Arping and Sautner (2010).

Model 9 also provides important results in terms of control variables. Regression results show that larger companies can have more debt in capital structures and have the ability to regulate their capital structures accordingly. This result in the context of firm size is consistent with the result found by Arping and Sautner (2010). However, this study reveals that liquidity of companies has a negative impact on leverages.

\section{CONCLUSION}

In financial markets, regulatory bodies are responsible for the safe, effective and stable functioning and development of markets. In the context of corporate governance, the establishment of a transparent and accountable environment and the protection of the rights and interests of investors are added. As an important actor of the corporate governance environment, regulators are taking precautions to prevent the dominating shareholders, investors and creditors from seizing their rights and interests.

It is expected that the management of companies in a holistic approach within the framework of corporate governance, being fair, transparent, accountable and responsible will provide financial and non-financial benefits not only to their stakeholders but also to the company itself. However, this theoretical point of view does not always occur in practice, and may cause that those who control or manage the company may use the company's resources to their interests. Practices such as presence of independent and non-executive members, committees, increasing transparency, and electronic general meeting systems stem from the consequences of potential conflict of interest. Corporate governance regulations try to intervene indirectly in companies and their management. However, the effect of these interventions is not always clear. All these uncertainties formed the main motivation for this study.

The purpose of this study is to determine whether corporate governance regulations have an impact on the board and capital structures of companies listed on Borsa Istanbul (BIST). The study consists of 134 companies listed in BIST Industry Index between 2010-2014. After 2011, Turkey changed its governance policy and made structural reforms in the field of corporate governance. Some basic principles such as independence criteria, independent members, audit, risk and board committees were mandatory. The study analyzes whether these regulations are effective in general.

All data used in the study were obtained from publicly available sources such as annual report, corporate governance compliance report, independent audit report and financial statements submitted by the companies to regulatory bodies. Tests for non-financial variables are analyzed using non-parametric statistical methods (Cochran's Q, McNemar, Friedman and Wilcoxon tests). The effect of regulations on capital structure is analyzed by creating an econometric model.

In the study, starting with the effect of regulations on general corporate governance quality is investigated. The quality of corporate governance is considered as an element that may affect the management structure. Cochran's $Q$ test results indicate a statistically significant difference on general corporate governance quality after regulation compared to before. The McNemar test after this test points out that the effect of the regulations is reflected minimum after three years. This result can be interpreted as the positive effect of the policy change on the quality of corporate governance will not be as short as 1 or 2 years.

Legislation in Turkey does not require companies to establish an internal audit system. However, the reform in 2011 mandated companies to establish an audit committee until June 2012. Second, this study investigate whether reform could 
affect companies in establishing internal audit systems. Both Cochran's $Q$ test and McNemar test indicate that corporate governance regulations have an impact on public companies establish internal audit systems. These results point out that the requirement of the audit committee to drive companies to set up an internal audit system.

Thirdly, it is examined whether the requirement for independent members has been fulfilled. The expected result was that companies comply with the regulations, which is also statistically proven by Cochran's $Q$ test. Besides, the main objective is to examine the pre-regulatory actions of the companies. The principle that companies had independent members on their boards had been included to the CMD Corporate Governance Code since 2003, but compliance was voluntary. Analysis results indicate that a significant proportion of companies (about $81 \%$ ) waited to elect independent members until 2012 when the regulation would enter into force.

Fourth, in this study, effect of corporate governance regulations on board structures of companies are investigated by three models. The number of members of the board represents the management structure. Friedman test results show that the effect of corporate governance regulations on the structure of the board is statistically significant in all three models. After the Wilcoxon test, this significance is confirmed, but it is seen that the companies acted not in the year of the regulations, but in the year in which the regulations regarding the independent member came into force. This finding, together with the previous result, is actually the key point of the study and shows why mandates are essential.

Finally, the effect of the regulations on the capital structures of the companies is investigated with panel data analysis. Book leverage is a dependent variable representing the capital structure. In both the pooled regression method and fixed effect method, it is determined that the corporate governance regulations entered into force in 2012 did not affect the leverage of the companies. This analysis also provides important results in terms of control variables. The results of the regression show that larger companies can use more credit and have the opportunity to regulate their capital structures accordingly. This result is consistent with the result founded by Arping and Sautner (2010). On the other hand, the study shows that liquidity reduces book leverage of public companies.

When the study is examined as a whole, it points to the necessity of the regulations and enforcements for public companies in the field of corporate governance. In the years when regulations are loose and in countries with weak legal protection, investors are at risk of being exploited by dominant shareholders. However, as much as enacting laws, their enforcement, monitoring and sanctions are also important. It is recommended to regulatory bodies to concentrate more on these critical issues.

This study has important contributions to both literature and policy makers. In spite of the fact that many studies in the literature are reported on the effects of regulations in developed countries (such as SOX), there are not enough studies on the results of corporate governance regulations for emerging markets. Furthermore, no study has found in the literature that examines the effect of regulations on both management and board and financial aspects. This study is expected to fill the gap in the literature in this respect. Nonetheless, the most important limitation is that the study only covers Turkey and the industrial companies in Turkey. Thus, the results should not be generalized. It is recommended that those who study on this issue in the future should be extended to more developing countries.

\section{REFERENCES}

Abdallah, A. A.-N., \& Ismail, A. K. (2017). Corporate governance practices, ownership structure, and corporate performance in the GCC countries. Journal of International Financial Markets, Institutions and Money, Vol. 46 , 98-115.

Acaravcı, S. K., Kandır, S. Y., \& Zelka, A. (2015). Kurumsal Yönetimin BIST Şirketlerinin Performanslarına Etkisinin Araştırıl ması. Niğde Üniversitesi iiBF Dergisi, Vol. 8(1) , 171 -183.

Achim, M.-V., \& Borlea, S.-N. (2014). The Assessment of Corporate Governance System Quality in the Romanian Sectors. Analysis of the Companies Listed on the Bucharest Stock Exchange. Procedia Economics and Finance, Vol.15, 617-625.

Aksu, M., \& Kösedağ, A. (2006). Transparency and Disclosure Scores and Their Determinants in the Istanbul Stock Exchange. Corporate Governance: An International Review, Vol. 14, No. 4 , 277-296.

Anderson, A., \& Gupta, P. P. (1999). A cross-country comparison of corporate governance and firm performance: Do financial structure and the legal system matter? Journal of Contemporary Accounting \& Economics, Vol.5(2) , 61-79.

Angrist, J. D., \& Krueger, A. B. (1999). Empirical Strategies in Labor Economics. O. C. Ashenfelter, \& D. Card Eds. in., Handbook of Labor Economics, Vol. 3, Part A (p. 1277-1366). North Holland: Elsevier.

Arora, A., \& Sharma, C. (2016). Corporate governance and firm performance in developing countries: evidence from India. Corporate Governance, Vol.16(2) , 420-436.

Arping, S., \& Sautner, Z. (2010). Corporate governance and leverage: Evidence from a natural experiment. Finance Research Letters, Vol.7(2) , 127-134. 
Arsov, S., \& Bucevska, V. (2017). Determinants of transparency and disclosure - evidence from post-transition economies. Economic Research-Ekonomska Istraživanja, Vol. 30, No. 1 , 745-760.

Azeez, A. (2015). Corporate governance and firm performance: evidence from Sri Lanka. Journal of Finance and Bank Management, Vol.3(1) , 180-189.

Bauer, R., Guenster, N., \& Otten, O. (2004). Empirical evidence on corporate governance in Europe: The effect on stock returns, firm value and performance. Journal of Asset Management, Vol.5(2) , 91-104.

Baysinger, B. D., \& Butler, H. N. (1985). Corporate Governance and the Board of Directors: Performance Effects of Changes in Board Composition. Journal of Law, Economics, \& Organization, Vol.1(1) , 101-124.

Bhagat, S., \& Bolton, B. (2013). Director Ownership, Governance, and Performance. Journal of Financial and Quantitative Analysis, Vol.48(1) , 105-135.

BIST. (2019). Corporate Governance Index. Retrieved from https://www.borsaistanbul.com/en/indices/bist-stock-indices/corporategovernance-index

Black, B. S., de Carvalho, A. G., \& Gorga, É. (2012). What matters and for which firms for corporate governance in emerging markets? Evidence from Brazil (and other BRIK countries). Journal of Corporate Finance, Vol.18, 934-952.

Cadbury Commitee. (1992). Report of the Committee on the Financial Aspects of Corporate Governance. London: Gee Publishing.

Choi, J. J., Park, S. W., \& Yo, S. S. (2007). The Value of Outside Directors: Evidence from Corporate Governance Reform in Korea. Journal of Financial and Quantitative Analysis, Vol.42(4) , 941-962.

CMB. (2019). CMB Communiqués. Retrieved from http://www.cmb.gov.tr/SiteApps/Teblig/Index/n

CMB. (2003, 2005). Corporate Governance Principles: Capital Markets Boards of Turkey. Retrieved from http://www.cmb.gov.tr/Sayfa/Dosya/84

Cochran, W. (1950). The Comparison of Percentages in Matched Samples. Biometrika, Vol. 37, No. 3/4 , 256-266.

Detthamrong, U., Chancharat, N., \& Vithessonthi, C. (2017). Corporate governance, capital structure and firm performance: Evidence from Thailand. Research in International Business and Finance, Vol.42, 689-709.

Durnev, A., \& Kim, E. (2005). To Steal or Not to Steal: Firm Attributes, Legal Environment, and Valuation. Journal of Finance, Vol. 60, No. 3 , 1461-1493.

Eulerich, M., Kremin, J., \& Wood, D. A. (2019). Factors that influence the perceived use of the internal audit function's work by executive management and audit committee. Advances in Accounting, Vol.45 , 1-7.

Fama, E. F., \& Jensen, M. C. (1983). Separation of Ownership and Control. Journal of Law and Economics, Vol. 26, No. 2 , 301-325.

Ferris, S. P., \& Yan, X. (. (2007). Do independent directors and chairmen matter? The role of boards of directors in mutual fund governance. Journal of Corporate Finance, Vol.13(2-3) , 392-420.

Fleiss, J. L., Levin, B., \& Paik, M. C. (2003). Statistical Methods for Rates and Proportions, Third Edition. New Jersey: John Wiley \& Sons.

Garay, U., \& González, M. (2008). Corporate Governance and Firm Value: The Case of Venezuela. Corporate Governance: An International Review, Vol. 16, No. 3 , 194-209.

Germain, L., Galy, N., \& Lee, W. (2014). Corporate governance reform in Malaysia:Board size, independence and monitoring. Journal of Economics and Business, Vol.75, 126-162.

Gompers, P. A., Ishii, J. L., \& Metrick, A. (2003). Corporate Governance and Equity Prices. Quarterly Journal of Economics, Vol. 118, No. 1 107-155.

Grosman, A. (2015). Corporate Governance as a Mechanism to Mitigate Financing Constraints on Investment. Retrieved from https://papers.ssrn.com/sol3/papers.cfm?abstract_id=2638434

Hermalin, B. E., \& Weisbach, M. S. (1991). The Effects of Board Composition and Direct Incentives on Firm Performance. Financial Management, Vol.20(4) , 101-112.

Jiraporn, P., Kim, J.-C., Kim, Y. S., \& Kitsabunnarat, P. (2012). Capital structure and corporate governance quality: Evidence from the Institutional Shareholder Services (ISS). International Review of Economics and Finance, Vol.22 , 208-221.

Johl, S. K., Kaur, S., \& Cooper, B. J. (2015). Board characteristics and firm performance: Evidence from Malaysian public lis ted firms. Journal of Economics, Business and Management, Vol.3(2) , 239-243.

KAP. (2019). KAP Public Disclosure Platform. Retrieved from https://www.kap.org.tr/en/Endeksler

Khanna, T., Palepu, K. G., \& Srinivasan, S. (2004). Disclosure Practices of Foreign Companies Interacting with U.S. Markets. Journal of Accounting Research, Vol. 42, No. 2 , 475-508. 
Klapper, L. F., \& Love, I. (2004). Corporate Governance, Investor Protection, and Performance in Emerging Markets. Journal of Corporate Finance, Vol. 10 , No. 5 , 703-728.

Kose, J., \& Senbet, L. W. (1998). Corporate governance and board effectiveness. Journal of Banking \& Finance, Vol.22(4) , $371-403$.

Kumar, N., \& Singh, J. (2013). Effect of board size and promoter ownership on firm value: some empirical findings from India. Corporate Governance, Vol.13(1) , 88-98.

La Porta, R., De-Silanes, F. L., Shleifer, A., \& Vishny, R. W. (1998). Law and Finance. Journal of Political Economy, Vol. 106, No. 6, $1113-1155$.

Larcker, D. F., Ormazabal, G., \& Taylor, D. J. (2011). The market reaction to corporate governance regulation. Journal of Financial Economics, Vol.101(2) , 431-448.

Lou, W., \& Fu, J. C. (2007). On exact Type I and Type II errors of Cochran's test. Statistics \& Probability Letters, Vol.77(12) , $1282-1287$.

Mahzan, N., \& Yan, C. M. (2014). Harnessing the Benefits of Corporate Governance and Internal Audit: Advice to SME. Procedia - Social and Behavioral Sciences, Vol.115, 156-165.

Martynova, M., \& Renneboog, L. (2011). Evidence on the international evolution and convergence of corporate governance regula tions. Journal of Corporate Finance, Vol.17, 1531-1557.

Modigliani, F., \& Miller, M. H. (1958). The cost of capital, corporation finance and the theory of investment. The American Economic Review, Vol.48 (3) , 261-297.

Monks, R. A., \& Minow, N. (2004). Corporate Governance Third Edition. United Kingdom: Blackwell Publishing.

Mura, R. (2007). Firm Performance: Do Non-Executive Directors Have Minds of their Own? Evidence from UK Panel Data. Financial Management, Vol.36(3) , 81-112.

Nadarajah, S., Ali, S., Liu, B., \& Huang, A. (2018). Stock liquidity, corporate governance and leverage: New panel evidence. Pacific-Basin Finance Journal, Vol.50, 216-234.

Ntim, C. G., Opong, K. K., \& Danbolt, J. (2012). The Relative Value Relevance of Shareholder Corporate Governance Disclosure Policy Reforms in South Africa. Corporate Governance: An International Review, Vol. 20, No. 1 , 84-105.

OECD. (1999). OECD Principles of Corporate Governance. OECD Publications Service.

OECD. (2004). OECD Principles of Corporate Governance. OECD Publications Service.

OECD. (2015). OECD Principles of Corporate Governance. Retrieved from http://www.oecd.org/corporate/principles-corporategovernance.htm

Saha. (2019). Saha Rating Corporate Governance Rating Methodology. Retrieved from http://www.saharating.com/ saharati/en/services/corporate-governance-rating/corporate-governance-rating-methodology/

Sheskin, D. (2000). Handbook of Parametric and Nonparametric Statistical Procedures 2nd Edition. Boca Raton, FL: Chapman \& Hall/CRC. Solomon, J., \& Solomon, A. (2004). Corporate Governance and Accountability. England: John Wiley \& Sons, Ltd

THEIAA. (n.d.). About Internal Auditing. Retrieved from https://global.theiia.org/about/about-internal-auditing/Pages/About-InternalAuditing.aspx

Torres-Reyna, O. (2007). Panel Data Analysis. Fixed and Random Effects using Stata (v. 4.2). Retrieved from https://www.princeton.edu/ otorres/Panel101.pdf

Tulung, J. E., \& Ramdani, D. (2018). Independence, Size and Performance of the Board: An Emerging Market Research. Corporate Ownership \& Control, Vol.15(2) , 201-208.

TUSIAD. (2002). Corporate Governance Code of Best Practice: Composition and Functioning of the Board of Directories. Retrieved from https://www.tusiad.org/en/reports/item/9238-corporate-governance-code-of-best-practice-composition-and-functioning-of-the-board-ofdirectories

Wang, M., \& Hussainey, K. (2013). Voluntary forward-looking statements driven by corporate governance and their value relevance. Journal of Accounting and Public Policy, Vol. 32, Issue 3 , 26-49.

West, A. (2009). Corporate Governance Convergence and Moral Relativism. Corporate Governance: An International Review, Vol.17, No.1 , 107-119.

Wintoki, M. B., \& Xi, Y. (2019). Friendly directors and the cost of regulatory compliance. Journal of Corporate Finance, Vol.58 , 112-141.

Yermack, D. (1996). Higher market valuation of companies with a small board of directors. Journal of Financial Economics, Vol.40 , $185-211$.

Zhu, J., Ye, K., Tucker, J. W., \& Chan, K. C. (2016). Board hierarchy, independent directors, and firm value: Evidence from China. Journal of Corporate Finance, Vol.41, 262-279. 